\title{
In-Hospital Outcomes and Predictors of Mortality in Acute Myocardial Infarction with Cardiogenic Shock Treated with Primary Angioplasty: Data from the InCor Registry
}

\author{
Igor Ribeiro de Castro Bienert, Henrique Barbosa Ribeiro, Leandro Richa Valim, \\ Carlos Augusto Homem de Magalhães Campos, Augusto Celso Lopes Jr., Rodrigo Barbosa Esper, \\ Luiz Junya Kajita, Antonio Esteves Filho, Marcus Nogueira da Gama, Pedro Eduardo Horta, \\ Gilberto Guilherme Ajjar Marchiori, Andre Gasparini Spadaro, Silvio Zalc, Paulo Rogério Soares, \\ Marco Antonio Perin, Pedro Alves Lemos Neto, Expedito Eustáquio Ribeiro da Silva
}

\begin{abstract}
Background: Cardiogenic shock is the leading cause of death in patients with ST-segment elevation myocardial infarction (STEMI). The present study evaluated patients with STEMI and cardiogenic shock undergoing primary percutaneous coronary intervention, in order to establish their profile and predictors of in-hospital mortality. Methods: A single centre registry, including 100 patients evaluated from 2001 to 2009, was used to compile clinical, angiographic and procedure-related characteristics and in-hospital outcomes. The independent predictors of in-hospital mortality were determined by multivariate analysis. Results: A high prevalence of risk factors was observed. The angiographic success rate was $92 \%$, despite the lesion complexity $(83.1 \%$ were type $\mathrm{B} 2 / \mathrm{C})$. The left anterior descending artery was the most affected artery $(45 \%)$, and $73 \%$ of the patients had multivessel disease. The mortality rate was $45 \%$, and its independent predictors were multivessel disease (odds ratio [OR] 2.62; $95 \%$ confidence interval $[95 \% \mathrm{CI}] 1.16-5.90)$ and TIMI flow $<3$ at the end of the procedure (OR 2.11; $95 \% \mathrm{Cl}$ 1.48-3.02). Conclusions: Patients with STEMI complicated by cardiogenic shock presented high-risk clinical and angiographic characteristics, and despite the high angiographic success rate of the procedure, mortality rates were high. The presence of multivessel disease and TIMI flow $<3$ at the end of the procedure were independent predictors of mortality.
\end{abstract}

DESCRIPTORS: Angioplasty. Myocardial infarction. Shock, cardiogenic. Mortality.
RESUMO

\section{Desfechos Intra-Hospitalares e Preditores de Mortalidade no Infarto Agudo do Miocárdio com Choque Cardiogênico Tratados por Angioplastia Primária: Dados do Registro InCor}

Introdução: O choque cardiogênico é a maior causa de morte em pacientes com infarto agudo do miocárdio com supradesnivelamento do segmento de ST (IAMCSST). O presente estudo avaliou pacientes com IAMCSST e choque cardiogênico submetidos a intervenção coronária percutânea primária com o objetivo de estabelecer seu perfil e os preditores de mortalidade hospitalar. Métodos: Registro unicêntrico, incluindo 100 pacientes avaliados no período de 2001 a 2009 quanto a características clínicas, angiográficas e do procedimento, e a desfechos intra-hospitalares. Por análise multivariada foram determinados preditores independentes da mortalidade hospitalar. Resultados: Com relação às características clínicas, foi observada alta prevalência de fatores de risco, sendo a taxa de sucesso angiográfico de $92 \%$, apesar da complexidade das lesões ( $83,1 \%$ do tipo B2/C). A artéria mais acometida foi a descendente anterior $(45 \%)$, tendo o padrão multiarterial ocorrido em $73 \%$ dos casos. A taxa de mortalidade foi de $45 \%$, sendo seus preditores independentes o padrão multiarterial [odds ratio (OR) 2,62; intervalo de confiança de 95\% (IC 95\%) 1,16-5,90] e o fluxo coronário TIMI $<3$ ao final do procedimento (OR 2,11, IC 95\% 1,48-3,02). Conclusões: Os pacientes com IAMCSST complicado por choque cardiogênico apresentaram características clínicas e angiográficas de alto risco e, apesar do alto sucesso angiográfico do procedimento, altas taxas de mortalidade. Foram preditores independentes de mortalidade o padrão multiarterial e fluxo $\mathrm{TIMI}<3$ ao final do procedimento.

DESCRITORES: Angioplastia. Infarto do miocárdio. Choque cardiogênico. Mortalidade.

Instituto do Coração of the Hospital das Clínicas of the Faculdade de Medicina of the Universidade de São Paulo (InCor/HCFMUSP) - São Paulo, SP, Brazil.

Correspondence to: Igor Ribeiro de Castro Bienert. Serviço de Cardiologia Intervencionista - Hospital das Clínicas da Faculdade Estadual de Medicina de Marília (FAMEMA) Rua Aziz Atallah, s/n - Bairro Fragata - Marília, SP, Brazil - CEP 17519-101

E-mail: bienert@famema.br

Received on: 12/19/2011 • Accepted on: 3/1/2012 
C ardiogenic shock is the major cause of death in patients with ST-segment elevation myocardial infarction (STEMI). ${ }^{1}$ Nevertheless, cardiogenic shock can also occur in a later phase of STEMI, especially from causes other than acute ventricular dysfunction, such as mechanical complications due to acute mitral valve regurgitation and free wall rupture or interventricular septum rupture. ${ }^{2-5}$

In this context, mortality rates are still high, varying between $42 \%$ and $48 \%$ in more recent studies. ${ }^{2,6,7}$ Between 1995 and 2004, temporal analysis has shown a reduction of this outcome $(60.3 \%$ vs. $47.9 \% ; \mathrm{P}<0.001)$, especially when patients underwent early percutaneous coronary intervention (PCl), with more benefits becoming evident during the hospital stay. ${ }^{2}$ The concept of early $\mathrm{PCl}$ intervention is important because although studies do not show differences between death rates related to the chosen revascularisation method, ${ }^{8}$ in clinical practice, over $60 \%$ of the patients with STEMI and cardiogenic shock admitted to hospitals undergo early $\mathrm{PCl}$, and emergency coronary artery bypass graft surgery is performed in less than $5 \%$ of the cases.

There are few studies concerning the Brazilian population with STEMI admitted to hospitals, and the data regarding cardiogenic shock are derived from small subgroups. ${ }^{3,9,10}$ Therefore, the present study aimed to evaluate the clinical and angiographic features, as well as the in-hospital outcomes, of consecutive patients with STEMI and cardiogenic shock who were admitted to this institution. In addition, the independent predictors of in-hospital mortality were determined through multivariate analysis.

\section{METHODS}

\section{Study population}

In the present study, patients with STEMI undergoing primary percutaneous coronary intervention in a single centre (Instituto do Coração of the Hospital das Clínicas of the Faculdade de Medicina of the Universidade de São Paulo - InCor/HCFMUSP, São Paulo, SP, Brazil) were evaluated between January of 2001 and May of 2009. The analysis included all patients with cardiogenic shock who were admitted to the hospital and treated percutaneously.

\section{Procedure}

Platelet anti-aggregation therapy consisted of using 300-600 mg loading dose of clopidogrel, followed by a dose of $75 \mathrm{mg} /$ day for at least 30 days for patients treated with bare-metal stents and one year for those with drug-eluting stents. Additionally, patients received a loading dose of 150-300 mg of aspirin and a maintenance dose of $100 \mathrm{mg} /$ day for an indefinite period of time. After obtaining the vascular access site $(>6$ $\mathrm{F}$; femoral in all cases) and introducing the catheter, heparin was administered at the recommended dose in order to obtain an activated clotting time $>250$ seconds (or > 200 seconds if glycoprotein IIb/IIla inhibitors were used). Stents of 2.5 to $4 \mathrm{~mm}$ in diameter and 8 to $33 \mathrm{~mm}$ in length were available for use. The surgeon was responsible for choosing to use either a stent with balloon pre-dilatation or a directly implanted stent. Manual thrombus aspiration catheters were not available for use in these patients.

\section{Data collection and analysis}

Data regarding in-hospital evolution were collected by trained doctors during the hospital stay through previously standardised forms. Data collection included clinical features, results of laboratory examinations, data from the invasive procedure (from the time of the exam until the angiographic and intervention characteristics were determined), and clinical evolution until discharge from the hospital.

\section{Definitions}

Using electrocardiograms, STEMI was diagnosed in the presence of persistent ST-segment elevation $>1 \mathrm{~mm}$ in two contiguous derivations or a new left bundle branch block. Cardiogenic shock was defined by clinical criteria according to the study 'Should We Emergently Revascularize Occluded Coronaries for Cardiogenic Shock (SHOCK).' The criteria included the presence of hypotension (maintaining systolic arterial pressure $<90 \mathrm{mmHg}$ for at least 30 minutes or adopting support measures to maintain systolic arterial pressure $>90 \mathrm{mmHg}$ ) and organic hypoperfusion (urine output $<30 \mathrm{~mL} /$ hour and heart rate $>60 \mathrm{bpm}) .{ }^{11}$

The morphology of the lesions was classified according to the definitions of the American College of Cardiology/American Heart Association (ACC/AHA), which were modified by Ellis et al. ${ }^{12}$ Angiographic success was defined as a $<30 \%$ reduction of the target lesion and maintaining or re-establishing normal antegrade flow (TIMI 3)..$^{13}$ The angiographic presence of a thrombus was defined as the abrupt interruption of the vessel flow with retention of contrast, or as a failure related to overfilling in patent vessels ('negative image') above or adjacent to a region of stenosis. ${ }^{14}$

A $25 \%$ increase in basal serum creatinine or an increase of $0.5 \mathrm{mg} / \mathrm{dL}$ of serum creatinine during the period between two and seven days after performing the procedure was considered as acute renal failure. ${ }^{15}$ The evaluated vascular complications included pseudo-aneurysm, arteriovenous fistula, significant haematoma at the access site $(>10 \mathrm{~cm})$, distal embolisation and/or ischaemia related to the puncture site, and bleeding through the access site, which was defined as a haemoglobin decrease of $>2 \mathrm{~g} / \mathrm{dL}$ or as the necessity for a blood transfusion. Death was defined as resulting from any cause. ${ }^{16}$ 


\section{Statistical analysis}

Continuous variables were reported as means \pm standard deviation, and categorical variables were represented as percentages. The clinical and angiographic features shown in Tables 1 and 2 were included in a regression model to provide multivariate detection of the mortality predictors.

All tests were two-tailed and $\mathrm{P}<0.05$ was considered significant. The analyses were performed with the Statistical Package for Social Sciences (SPSS) version 17.0 program (SPSS Inc. - Chicago, USA).

\section{RESULTS}

Table 1 presents the clinical features of the 100 patients included in the study. The majority of the patients were males (64\%), and the mean age was $64.8 \pm 14$ years. The most prevalent clinical risk factors were systemic arterial hypertension (73\%), dyslipidaemia $(63 \%)$ and diabetes mellitus $(32 \%)$. One-fourth of the patients had previous acute myocardial infarction (AMI), and the same proportion of the patients smoked. Other antecedents were presence of heart failure in $22 \%$, previous $\mathrm{PCl}$ in $12 \%$ and previous coronary artery bypass graft surgery in $14 \%$.

TABLE 1

Clinical Features

\begin{tabular}{lc}
\hline & $\mathbf{n}=\mathbf{1 0 0}$ \\
\hline Age, years & $64.8 \pm 14$ \\
Male gender, \% & 64 \\
Diabetes mellitus, \% & 32 \\
Systemic arterial hypertension, \% & 73 \\
Dyslipidaemia, \% & 63 \\
Smoking, \% & 25 \\
Prior coronary artery bypass graft & 14 \\
surgery, \% & \\
Prior percutaneous coronary & 12 \\
intervention, \% & \\
Previous acute myocardial infarction, \% & 25 \\
Congestive heart failure, \% & 22 \\
Dialytic chronic renal failure, \% & 4 \\
Chronic obstructive pulmonary disease, $\%$ & \\
Previous stroke, \% & \\
\hline n = number of patients. & \\
\hline & \\
\hline
\end{tabular}

Table 2 summarises the angiographic and procedurerelated features. Most of the lesions were classified as B2/C lesions (83.1\% of the cases) with multivessel disease in most of them (73\%). TIMI 0/1 flow prior to the procedure was observed in $85 \%$ of the cases. Most of the interventions were performed in the anterior descending area (45\%), and there was a low incidence of intervention in the left main coronary artery $(8 \%)$ and of surgical grafts (9\%). Angiographic success was $92 \%$, with a mean of $1.4 \pm 0.4$ lesions/patient and $2 \pm 0.7$ stents/patient.

Table 3 presents the clinical outcomes and in-hospital complications. The in-hospital death rate was $45 \%$, and $3 \%$ of the patients needed re-intervention. Among the cases of intervention, one patient was treated in a site different from the initial lesion, one patient had acute stent thrombosis occur during the procedure, and one patient had sub-acute stent thrombosis three days after the angioplasty. The most prevalent clinical complications were: acute renal failure $(10 \%$; half of the cases required dialysis), haemotransfusion (2\%) and stroke (2\%). In $2 \%$ of the cases, vascular complications were found, and all these complications were due to access site bleeding. There were no cases of pseudo-aneurysm or arteriovenous fistula.

Multivessel disease (odds ratio [OR] 2.62; 95\% confidence interval [95\% CI] 1.16-5.90) and TIMI $<3$

TABLE 2

Angiographic and Procedure-related Characteristics

$\mathrm{n}=100$ patients/

132 lesions

\begin{tabular}{lc} 
Vessel disease & 27 \\
Single vessel & 27 \\
Double vessel & 46 \\
Triple vessel & 83.1 \\
Type B2/C lesion (ACC/AHA), \% & 23.3 \\
Ostial lesion, \% & 42.2 \\
Ulcerated lesion, \% & 67.3 \\
Eccentric lesion, \% & 68.8 \\
Thrombus, \% & 22.3 \\
Bifurcation, \% & $1.4 \pm 0.4$ \\
Treated lesions (lesions/patient) & $2 \pm 0.7$ \\
Stents used (stents/patient) & $2.96 \pm 0.3$ \\
Stent diameter, mm & 17 \\
Use of intra-aortic balloon, \% & 92 \\
Angiographic success, \% & \\
\hline ACC/AHA = American Heart Association/American College \\
of Cardiology.
\end{tabular}


TABLE 3

In-hospital Outcomes and Complications

\begin{tabular}{lc}
\hline & $\mathbf{n = 1 0 0}$ \\
\hline Death, \% & 45 \\
Stroke, \% & 2 \\
Reintervention, \% & 3 \\
Vascular complications, \% & 2 \\
Access site bleeding & 2 \\
Pseudo-aneurysm or arteriovenous fistula & 0 \\
Transfusion needed, \% & 2 \\
Acute renal failure, \% & 10 \\
Dialysis needed, \% & 5 \\
\hline
\end{tabular}

Stroke $=$ ischaemic or hemorrhagic; $\mathrm{n}=$ number of patients.

TABLE 4

Variables that Independently Interfered in In-hospital Mortality

\begin{tabular}{lc}
\hline Variable & $\begin{array}{c}\text { Adjusted OR } \\
\mathbf{( 9 5 \%} \mathbf{~ C I})\end{array}$ \\
\hline $\begin{array}{l}\text { TIMI }<3 \text { flow at the end } \\
\text { of procedure }\end{array}$ & $2.11(1.48-3.02)$ \\
Multivessel disease & $2.62(1.16-5.90)$ \\
\hline $\mathrm{Cl}=$ Confidence interval; OR = odds ratio. \\
\hline
\end{tabular}

coronary flow at the end of procedure (OR $2.11 ; 95 \% \mathrm{Cl}$ 1.48-3.02) (Table 4) were identified as independent predictors of death.

\section{DISCUSSION}

Cardiogenic shock is the major cause of death in patients admitted with STEMI. Despite treatment advances over the years, such as revascularisation through $\mathrm{PCl}$ or through coronary artery bypass graft surgery and the use of powerful anticoagulant and antiplatelet agents, death rates are still high. Few studies about the Brazilian population with STEMI admitted to hospitals have been conducted. ${ }^{3,9,10}$ Therefore, the present study aimed to consecutively characterise the patients with STEMI and cardiogenic shock admitted to a highly complex cardiology service according to their clinical and angiographic features. This study also aimed to characterise the predictors of in-hospital mortality for these patients.

In the present sample, patients with a high prevalence of risk factors, high angiographic complexity and high thrombus load were identified. The fact that the most impaired artery was the left anterior descending artery $(45 \%)$ can be explained by the increased risk for blockage in that myocardial area. Nevertheless, multivessel disease was present in $73 \%$ of the patients. Despite the high success rate of the procedure (92\%), in-hospital mortality was $45 \%$. The re-intervention rate at 30 days was $3 \%$. The rates of other clinical complications can be considered low, considering the complexity of the patients.

Previous studies in the literature have indicated that even in the $\mathrm{PCl}$ era, mortality rates are still high in patients with cardiogenic shock admitted to the hospital. Among these studies, the $\mathrm{SHOCK}^{4}$ trial, published in 2003 which involved patients treated between 1993 and 1998, must be highlighted. In this trial, in addition to the high prevalence of high-risk clinical and angiographic factors, the mortality rate was $39 \%$ the successfully treated cases, and $85 \%$ in the cases without a successful procedure. All patients with TIMI 0 or 1 flow died at the end of the intervention. In the six-year follow-up, the strategy of early reperfusion resulted in a relative reduction of $67 \%$ in mortality in comparison with the strategy of initial clinical compensation. ${ }^{17}$ Comparing that data with the results in this study, it can be observed that among the eight patients with TIMI flow $<3$, only one patient with TIMI 1 flow survived the hospital stay. Likewise, multivessel angiographic disease (OR 2.62; 95\% Cl 1.16-5.90) and TIMI flow $<3$ at the end of the procedure (OR 2.11; 95\% Cl 1.48-3.02) were independent predictors of mortality in this study.

Another recent study comparing the mortality rates during 35 years of evolution of the treatment of cardiogenic shock revealed a significant reduction in mortality rates over time $(76 \%$ in the 1980 s, $65.6 \%$ in the 1990s, and $42 \%$ since 2000). These percentages are similar to those found in the present population. ${ }^{7}$

Concerning the predictors of mortality patients admitted with cardiogenic shock several studies have demonstrated that the arterial pattern and the left ventricular function are the main prognostic markers. ${ }^{18,19}$ Among the predictors related to the procedures, the use of stents and a TIMI 3 flow at the end of the intervention correlated with a better prognosis, ${ }^{4}$ corroborating the previously mentioned outcomes of the Brazilian population.

\section{Limitations of the study}

Regarding the ventricular function, since this is a reference service that provides primary $\mathrm{PCl}$, and thus patients are sent directly to the interventional laboratory, the ventricular function of almost all patients was not evaluated before the procedure; it was only evaluated in the post-PCl hospitalisation. Therefore, it could not be determined whether the ventricular function in this population was a predictor of mortality. 
In the present sample, the use rate of the intraaortic balloon was low, despite the clinical and angiographic complexity and the presence of cardiogenic shock. Nevertheless, a recent study was published by the authors, with consecutive patients who underwent high-risk $\mathrm{PCl}$ with an intra-aortic balloon, in which the mortality rate was even higher $(61.2 \%)$. Similarly, both the TIMI flow and triple-vessel disease were predictors of events in that sample. ${ }^{16}$ It is unknown whether the greater use of an intra-aortic balloon in this population would have changed death rates.

It is also important to mention the lack of appropriate evaluation of the ischaemia duration as a limitation of the study. Many patients were directly transferred within the primary care network, in order to undergo angioplasty in other services, which limited the appropriate evaluation of pain-to-door time. In addition, during the initial years of the study, it was not possible to calculate the time at which the patients' arteries were opened, which also led to difficulty in evaluating the door-to-balloon time. The pain-to-door and door-to-balloon time variables could provide additional information, since both are significantly correlated with the mortality rate in the literature. ${ }^{4,18,19}$

\section{CONCLUSIONS}

The features of the patients with complicated AMI admitted to the hospital due to cardiogenic shock comprise high-risk clinical variables and complex angiographic features. Despite greater recent angiographic success rates of the procedure, its mortality rate is still high. In the present study, multivessel disease and the presence of TIMI 3 flow were independent predictors of mortality at the end of the procedure.

\section{CONFLICTS OF INTEREST}

The authors declare no conflicts of interest.

\section{REFERENCES}

1. Jeger RV, Radovanovic D, Hunziker PR, Pfisterer ME, Stauffer JC, Erne $\mathrm{P}$, et al. Ten-year trends in the incidence and treatment of cardiogenic shock. Ann Intern Med. 2008;149(9):618-26.

2. Babaev A, Frederick PD, Pasta DJ, Every N, Sichrovsky T, Hochman JS; NRMI Investigators. Trends in management and outcomes of patients with acute myocardial infarction complicated by cardiogenic shock. JAMA. 2005;294(4):448-54.

3. Nicolau JC, Serrano CV Jr, Garzon SA, Ramires JA. Prognosis of acute myocardial infarction in the thrombolytic era: medical evaluation is still valuable. Eur J Heart Fail. 2001;3(5):569-76.

4. Webb JG, Lowe AM, Sanborn TA, White HD, Sleeper LA, Carere RG, et al. Percutaneous coronary intervention for cardiogenic shock in the SHOCK trial. J Am Coll Cardiol. 2003;42(8):1380-6.

5. Zornoff LA, Paiva SA, Assalin VM, Pola PM, Becker LE, Okoshi MP, et al. Clinical profile, predictors of mortality, and treatment of patients after myocardial infarction, in an academic medical center hospital. Arq Bras Cardiol. 2002;78(4):396-405.
6. Alexander JH, Reynolds HR, Stebbins AL, Dzavik V, Harrington RA Van de Werf $F$, et al. Effect of tilarginine acetate in patients with acute myocardial infarction and cardiogenic shock: the TRIUMPH randomized controlled trial. JAMA. 2007; 297(15):1657-66.

7. Goldberg RJ, Spencer FA, Gore JM, Lessard D, Yarzebski J. Thirtyyear trends (1975 to 2005) in the magnitude of, management of, and hospital death rates associated with cardiogenic shock in patients with acute myocardial infarction: a population-based perspective. Circulation. 2009;119(9):1211-9.

8. White HD, Assmann SF, Sanborn TA, Jacobs AK, Webb JG, Sleeper LA, et al. Comparison of percutaneous coronary intervention and coronary artery bypass grafting after acute myocardial infarction complicated by cardiogenic shock: results from the Should We Emergently Revascularize Occluded Coronaries for Cardiogenic Shock (SHOCK) trial. Circulation. 2005;112(13): 1992-2001

9. Campos CAHM, Ribeiro HB, Ribeiro EE, Spadaro AG, Lemos PA, Perin $\mathrm{M}$, et al. Caracterização e impacto clínico tardio do noreflow associado a intervenção coronária percutânea primária vs. eletiva. Rev Bras Cardiol Invasiva. 2010;18(3):300-5.

10. Valim LR, Lopes Jr. AC, Bienert IRC, Ribeiro HB, Campos CA, Esper RB, et al. Infarto agudo do miocárdio complicado por choque cardiogênico: efeito da circulação colateral nos resultados da intervenção coronária percutânea primária - Dados do Registro InCor. Rev Bras Cardiol Invasiva. 2011;19(2):166-71.

11. Hochman JS, Sleeper LA, Webb JG, Sanborn TA, White HD, Talley JD, et al. Early revascularization in acute myocardial infarction complicated by cardiogenic shock. SHOCK Investigators. Should We Emergently Revascularize Occluded Coronaries for Cardiogenic Shock. N Engl J Med. 1999;341(9):625-34.

12. Ellis SG, Vandormael MG, Cowley MJ, DiSciascio G, Deligonul U, Topol EJ, et al. Coronary morphologic and clinical determinants of procedural outcome with angioplasty for multivessel coronary disease. Implications for patient selection. Multivessel Angioplasty Prognosis Study Group. Circulation. 1990;82(4):1193-202.

13. Mattos LA, Lemos Neto PA, Rassi Jr AJ, Marin-Neto JA, Sousa AGMR, Devito FS, et al. Diretrizes da Sociedade Brasileira de Cardiologia - intervenção coronária percutânea e métodos adjuntos diagnósticos em cardiologia intervencionista (II edição - 2008). Arq Bras Cardiol. 2008;91(4 Supl 1):1-58.

14. TIMI Study Group. The Thrombolysis in Myocardial Infarction (TIMI) trial. Phase I findings. N Engl J Med. 1985;312(14):932-6.

15. Lameire $N$, Van Biesen $W$, Vanholder $R$. Acute renal failure. Lancet. 2005;365(9457):417-30.

16. Conejo F, Santos LN, Ribeiro HB, Campos CA, Pozetti AH, Lopes Jr AC, et al. Evolução hospitalar de pacientes submetidos a assistência circulatória com balão intra-aórtico durante intervenção coronária percutânea de alto risco: Registro InCor. Rev Bras Cardiol Invasiva. 2011;19(4):392-99.

17. Hochman JS, Sleeper LA, Webb JG, Dzavik V, Buller CE, Aylward $\mathrm{P}$, et al. Early revascularization and long-term survival in cardiogenic shock complicating acute myocardial infarction. JAMA. 2006;295(21):2511-5.

18. Sanborn TA, Sleeper LA, Webb JG, French JK, Bergman G, Parikh $\mathrm{M}$, et al. Correlates of one-year survival inpatients with cardiogenic shock complicating acute myocardial infarction: angiographic findings from the SHOCK trial. J Am Coll Cardiol. 2003;42(8):1373-9.

19. Wong SC, Sanborn T, Sleeper LA, Webb JG, Pilchik R, Hart D, et al. Angiographic findings and clinical correlates in patients with cardiogenic shock complicating acute myocardial infarction: a report from the SHOCK Trial Registry. SHould we emergently revascularize Occluded Coronaries for cardiogenic shock? Am Coll Cardiol. 2000;36(3 Suppl A):1077-83. 